УДК 619:618.177:636.7

(C) 2013

Бордюгов К. С., Бордюгова С. С., Кот В. С., кандидати ветеринарних наук

Луганський національний аграрний університет

\title{
РІЗНІ МЕТОДИ ВИЗНАЧЕННЯ ОВУЛЯЩІї У СОБАК
}

Рецензент - доктор ветеринарних наук, професор В. Й. Іздепський

В оглядовій статті проаналізовані сучасні методи встановлення овуляиії у собак. Багато сук, яких вважають неплідними, - ие нормальні, здорові, фертильні тварини, чия вигадана нездатність народжувати пов'язана з нерозумінням фізіології розмноження їх власниками. Спарювання повинне плануватися під час фертильного періоду або, краще, періоду запліднення. Ці періоди можуть бути встановлені за допомогою різних методів (клінічна оцінка, лабораторні та інструментальні методи), які ми розглянули й проаналізували.

Ключові слова: собака, овулячуія, фертильність, неплідність, вагітність.

Постановка проблеми. У кожного власника племінної суки зустрічаються випадки, коли за нормального еструсу спарювання не завершується вагітністю, що стає суттєвою проблемою. У переважній більшості випадків це пов'язано 3 неправильним вибором терміну в'язки, коли неточно відрахували добу овуляції по відношенню до початку проеструсу.

Більшість власників практикують проведення парування або осіменіння на 10-14-у добу від проеструсу, однак це не завжди надійно, поскільки овуляція може відбутися на третю чи, навпаки, на 21-шу, значно рідше - на 27-31-шу добу. Тому існує проблема вибору оптимального методу встановлення дня овуляції, щоб підібрати добу проведення в'язки.

Аналіз основних досліджень і публікацій, у яких започатковано розв'язання проблеми. Нормальний статевий цикл у суки схильний до значних варіацій, але деякі власники племінних собак сприймають їх за патологію [1]. Професійний лікар повинен диференціювати фізіологічні, але мало відомі, прояви статевого циклу сук від патологічних порушень $[5,9]$. Розуміння фізіології статевого циклу собак необхідне для результативного їх парування. Виявлення особистих відхилень, нормального прояву статевого циклу плідної суці - основа для правильної організації їі парування $[1,3,8,12]$.

Важливим аспектом є економічна доцільність парування сук. Іноді власник племінної собаки для одержання високо породистих цуценят по- винен їхати на в'язку до самця на досить значну відстань - під час перевезення займає декілька діб. Власник суки повинен бути впевненим у точній даті овуляції, тоді кошти, витрачені на перевезення й оплату за в'язку власнику племінного самця, будуть відшкодовані майбутніми цуценятами $[8,12]$.

Мета даної роботи - проаналізувати вітчизняні та закордонні дослідження присвячені різним методам визначення овуляції у собак.

Завдання: вибрати й рекомендувати найбільш оптимальний метод визначення овуляції у сук.

Матеріали і методи досліджень. Матеріалом були сучасні наукові та практичні знання стосовно різних методів визначення овуляції у собак. У ході виконання роботи користувалися методами порівняння та узагальнення.

Результати досліджень. Одним із найбільш доступних методів є клінічний огляд. На стадії збудження статевого циклу підвищується кров'яний тиск, змінюється склад крові, в органах статевої системи посилюються проліферативні процеси, викликані зміною нейрогуморального статусу організму. Статеве збудження (феномен) у більшості випадків співпадає з феноменом тічки (пустовки). Статеве збудження характеризується занепокоєнням, грайливістю, злобою, послабленням нюху у мисливських і службових собак, відмовою від корму, збільшенням молочних залоз, почервонінням слизової оболонки передвір'я піхви, виділенням зі статевої щілини слизу, який має особливий специфічний запах, що дає кобелю змогу відчувати його на значній відстані. У деяких сук внаслідок сильної гіперемії та набряклості слизової оболонки піхви iз вульви у вигляді півмісячного або кулеподібного утворення виступає набряклий сечостатевий клапан. Набряк слизової оболонки із закінченням охоти зменшується, а $з$ часом і повністю зникає.

Передтічка (проеструс) - тривалість даної фази становить у середньому 9 (3-16) діб. У цей час ростуть і зріють у яєчниках фолікули, в яких інтенсивно синтезуються естрогени (фолікулін), під впливом яких виникають і проявляються ха- 
рактерні зміни в органах статевої системи та в поведінці суки: збільшення статевої петлі (вульви), кров'янисті виділення 3 неї, часте сечовиділення, облизування вульви, неслухняність суки, загравання 3 кобелями, але відсутній рефлекс «нерухомості» (до спарювання не підпускає).

Eструс (тічка) - тривалість даної фази становить у середньому 6 (3-12) діб, коли тварина готова до спарювання (позитивний рефлекс «нерухомості»). У цей час петля збільшена, але менш соковита, виділення 3 неї світло-рожеві або безколірні. Усі дозрілі фолікули овулюють протягом 12-24 годин, але овуляція у сук супроводжується виходом недозрілих яйцеклітин, які стають здатними до запліднення лише через 3 доби перебування в яйцепроводі, а потім зберігають ії впродовж однієї доби. Спермії кобеля, які надходять в органи статевої системи суки, зберігають запліднюючу здатність до семи діб, що і $є$ критерієм більшості випадків або оптимальним часом для спарювання (в'язки), тобто це фактично на 2-4-у добу від прояву феномена охоти. Враховуючи можливості коливання строків початку овуляції, суку в'яжуть двічі, з інтервалом у 48 годин $[12,13]$.

Прийняття самця чи контрольного пробника та прояв рефлексу відведення хвоста не можуть бути основними ознаками овуляції. Деякі суки, наприклад, допускали в'язку вже з початку проеструсу, хоча овуляція наступала лише через 30 діб. Таким чином, поведінка багатьох сук слабо співпадає із гормональним фоном, що сприяє заплідненню. Чимало сук вступає у в’язку під час несправжньої вагітності, при інфекційному запаленні сечових шляхів чи за наявності кіст яєчників, із проявом німфоманії.

Одже, клінічне дослідження сук не завжди може давати 100 \% гарантії настання овуляції у них.

Доцільніше керуватися інструментальними та лабораторними методами визначення овуляції. Найпоширенішими 3 них є: зміни базальної температури, УЗД-діагностика, ендоскопія піхви, зміни електричного опору слизової оболонки піхви, вимірювання глюкози в піхвових виділеннях, кристалізація піхвового слизу, піхвова цитологія, зміна концентрації гормонів.

Метод вимірювання концентрації глюкози у піхвових виділеннях під час тічки. Вміст цукрів у цервікальному слизі має вагоме значення для створення умов виживання та запліднювальної здатності сперміїв. За нестачі цукрів і надлишку хлоридів, а також вільних іонів кальцію, знижується від'ємний електричний заряд i настає їх аглютинація [8]. Інших літературних даних і підтверджень науковими дослідами ми не знайшли. Цей метод не набув широкого практичного застосування, - його використовують лише окремі заводчики для визначення оптимального часу осіменіння сук.

Філоненко А. І. вважає, що підвищення температури nid час тічки проявляється лише у $27 \%$ тварин, а тому діагностична цінність цього методу є досить низькою і може використовуватися лише як допоміжний метод.

Допомогти встановити оптимальний час в'язки може також метод кристалізації піхвового слизу, зібраного з передньої частини піхви, однак, із нашого погляду, цей метод досить суб'єктивний і фізіологічно недосконалий, на що вказує можливість кристалізації слизу під час ановуляторних статевих циклів та при кістах яєчників. Висихаючи на предметному склі, слиз формує малюнок у вигляді листка папороті, що збігається 3 фолікулярною фазою та овуляцією, після чого він стає розмазаним, а пізніше взагалі зникає, що характеризує лютеїнову фазу статевого циклу. Максимальний ступінь кристалізації піхвового слизу у сук спостерігається, в середньом, за 2-3 доби до предовуляторного піку ЛГ. Цей метод уу собаківництві може бути корисним для визначення оптимального часу осіменіння сук у поєднанні з іншими.

Для проведення ультразвукового дослідження необхідна наявність апарата для дослідження із високочастотним трансдуктором 7,5-15,0 мГц. Сканування починають із області сечового міхура - акустичне вікно, обов'язкове дослідження обох рогів, якщо вони незмінені. У нормі товщина рогів 0,5-1,0 см, тіло матки - до 1,5 см, довжина - близько $3 \mathrm{~cm}$, шийка візуалізується як скошена гіперехогенна трубчата структура. В фазу проеструсу та еструсу товщина рогів збільшена на 1-3 мм, рідини - мінімальна кількість. Яєчники у нормі під час проеструсу мають округлу чи овальну форму гіпоехогенної структури, під час еструсу - бугристі, 3 округлими анехогенними множинними кістозними структурами [4].

Електрометричний метод визначення оптимального часу осіменіння базується на зміні електричного опору слизової оболонки піхви. Методика заснована на тому, що електричний опір слизової оболонки піхви зменшується у пізню фазу еструсу; широко використовується для визначення оптимального часу осіменіння BPX [6, 10], сріблястих лисиць, зокрема у Норвегії [15] та собак службових порід [2, 3]. Доведено коре- 
ляцію між електричним опором слизової оболонки та передовуляційною концентрацією гормону ЛГ. Має значення також місце знаходження зонда у статевих органах сук під час проведення вимірювань. Нині промисловість випускає прилади для визначення оптимального часу осіменіння сук російського виробництва «Охотник» i (більш поширений) польського виробництва фірми «DRAMINSKI». У міру дозрівання фолікулів електричний опір (450-600 Ом) різко знижується. Під час тічки при показниках опору слизової піхви 200-300 Ом шийка матки завжди відкрита, а при опорі понад 350 Ом може бути закритою або слабо відкритою. Оптимальний час осіменіння відмічено при 250-400 Ом [3].

Ендоскопія піхви - дослідження слизової оболонки піхви за допомогою ендоскопа. Методика розроблена на основі змін, що відбуваються в організмі суки під час статевого циклу. У ході огляду звертають увагу на контури та окреслення складок, колір слизової оболонки піхви та наявність рідини. Під час проеструсу встановлюють набряк складок піхви. Під дією естрогенів відбувається реплікація шарів слизової оболонки піхви та її набряк, змінюється просвіт піхви та збільшується кількість складок, змінюється колір слизової оболонки. Збільшення рівня прогестерону в ході овуляції призводить до зменшення набряку, а на складках з'являються зморшки $[3,5,9]$. Значна вартість даних пристроїв та маніпуляцій на них і певні незручності, що виникають під час дослідження агресивних та неспокійних собак, - недоліки цього методу.

Піхвова изитологія - цитологічна діагностика клітинного складу зі слизової оболонки піхви залишається практичним, простим i недорогим методом визначення оптимального часу осіменіння сук. На гістологічну будову епітелію впливають гормони. Підвищений рівень естрогенів у крові сук викликає потовщення слизової оболонки піхви та збільшення кількості шарів клітин. У нормі в мазку виділень піхви можна знайти клітини покривного багатошарового плоского епітелію піхви і піхвової частини шийки матки, які належать до поверхневого й проміжного шарів, встановлюють відсоткове співвідношення зазначених клітин слизової оболонки піхви, а також фазу циклу та приблизний час в'язки. Поява клітин базального шару спостерігається за патологічних процесів у статевих органах $[3,5,9]$.

У мазках на початку фази проеструсу переважають проміжні клітини (деякі 3 яких кератинізовані). Спостерігається значна кількість ерит- роцитів; лейкоцити відсутні. У перші дві доби в мазках знаходять також поверхневі та парабазальні клітини, незначну кількість лейкоцитів. У середині фази проеструсу продовжує зростати кількість некератинізованих проміжних клітин, більшість із яких мають пікнотичні ядра. У кінці фази проеструсу зменшується кількість проміжних клітин, спостерігається збільшення поверхневих, характерна поява клітин, які не мають ядер. Із настанням фази тічки в крові різко підвищується рівень гормону естрадіолу, що призводить до збільшення кількості повністю ороговілих та кератинізованих епітеліальних клітин. Оптимальним строком для в'язки слід вважати той день, коли в препараті піхвового мазка поверхневі клітини майже на 80-90 \% без'ядерні $[1,7,14]$. Хоча в деяких випадках, коли інтерпритація мазків викликає сумніви чи отримані результати аналізу не співпадають із клінічною картиною, коли суку треба везти в інше місто, a інколи i державу, для проведення в'язки чи штучного запліднення, власник у змозі доповнити цей аналіз більш надійним методом, а саме кількісним встановленням рівня прогестерону в крові.

Відомо, що протягом усього періоду тічки відбувається каскад гормональних реакцій. Так, у передтічкову фазу (проеструс) підвищується рівень естрогенів, однак $\epsilon$ низьким рівень ЛГ i прогестерону у крові. У фазу тічки рівень естрогенів падає та починає підвищуватися рівень прогестерону.

Прогестерон (Р4) представляє собою індикатор овуляції у сук. Вона настає, коли показник P4 перевищує рівень 5-8 ng/ml.

Протягом двох-трьох діб після овуляції відбувається період повного дозрівання яйцеклітин. Періодом фертильності вважають 2-5-у добу після овуляції. Використання комплекту тесту Target, щоб визначити дату овуляції у собаки, повинно розпочинатися із 3-4-ї доби після першого дня проеструсу й продовжуватися через добу до першого визначення середніх концентрацій (більше ніж 1 нг/мл, менше ніж 5 нг/мл). Щоденний контроль плазми до визначення високої (5 нг/мл і більше) концентрації відбувається для того, щоб визначити дату овуляції. Оптимальний час в'язки - на другу чи третю добу після першої появи високих плазмових концентрацій прогестерону. Контрольна в'язка проводиться через 48 годин після першої [12-14].

Така ступінь достовірності визначення термінів овуляції дає змогу збільшити не тільки відсоток результативних запліднень, а й плодючість 
суки; чим точніше встановлений час овуляції, тим більше яйцеклітин зустрінуться зі сперміями і відбудеться запліднення.

Висновок. Кожен із зазначених методів має певні недоліки. Використання двох або трьох

\section{БІБЛІОГРАФІЯ}

1. Bотье M. Клинический подход к профилактике бесплодия у самки собак / М. Вотье // Ветеринар. - 1999. - № 10-12. - С. 31-32.

2. Деркач C. С. Динаміка електричного опору слизової оболонки піхви під час тічки у сук службових порід / С. С. Деркач // Науковий вісник ЛНУ вет. медицини та біотехнології ім. С. Ж. Гжицького.- 2010. - Том 12, № 2 (44), Ч. 2. C. $70-75$.

3. Деркач C. С. Діагностика оптимального часу осіменіння сук (клініко-експериментальні дані): автореф. дис. ... канд. вет. наук : спец. 16.00.07 «Ветеринарне акушерство» / С. С. Деркач. - К., 2011. - $20 \mathrm{c}$.

4. Інглед Д. Ультразвукове дослідження репродуктивних органів сук / Д. Інглед // Здоров'я дрібних тварин. -2006 . - № 4. - С. 8-10.

5. Ковальов П. В. Цитологічна картина мазків із піхви у сук / В. П. Ковальов // Науковий вісник Сумського НАУ. - 2003. - № 9. - С. 48-50.

6. Лотоцький В. В. Розробка і апробація сучасних методів визначення оптимального часу осіменіння високопродуктивних корів: автореф. дис. ... канд. вет. наук : спец. 16.00.07 «Ветеринарне акушерство» / В. В. Лотоцький. - К., 2008. -20 c.

7. Пибо Б. Определение концентрации прогестерона в репродукции собак /Б. Пибо, Ф. Пьерсон // Ветеринар. - 2002. - № 2. - С. 42-44.

8. Торрас Э. Дж. Эндокринология мелких домашних животных. Практическое руководство / методів одночасно збільшує відсоток встановлення точної дати овуляції. Ми вважаємо, що ця проблема буде актуальною і в подальших дослідженнях.

Э. Дж. Торрас, К. Т. Муни. - М.: ООО «Аквариум-Принт», 2006. -312 с.

9. Фонтбон А. Ошибки при анализе мазков, полученных из влагалища у собак / А. Фонтбон // Ветеринар. - 1999.- № 10-12. - С. 24-30.

10. Харута Г. Г. Діагностико-прогностичні показники електричного опору слизової оболонки піхви корів при осіменінні / Г. Г. Харута, В. В. Лотоцький // Вісник Білоцерківського держ. аграр. ун-ту : Зб. наук. праць. - 2003. Вип. № 25, Ч. 1. - С. 226-271.

11. Яблонський B. А. Проблеми відтворення тварин / В. А. Яблонський // Ветеринарна медицина України. - 2007. - № 3. - С. 42-44.

12. Appleyard $W$. T. The detection of oestrus in dairy cattle / W. T. Appleyard, B. Cook // Vet. Rek. - 2003. - № 99. - P. 253-256.

13. Ball P. G. Evaluation of tail paste as an oestrus detection aid using serial progesterone analysis / P. G. Ball, J. E. Cowpe, D. B Harker // Vet. Rek. 1983. - № 112. - P. 147-149.

14. Concannon P. W. Changes in LH, progesterone and sexual behavior associated with preovulatory luteinization in the bitch / P. W. Concannon, W. Hansel, K. McEntec // Biol. Reprod. - 1977. № 17. - P. 604-613.

15. Leidl W. Measurement of electrical resistance of the vaginal mucus as an aid for heat detection / W. Leidl, R. Stolla // Theriogenology.- 1976. № 6. - P. 237-249. 